considerable scope for incorporating the results of those trials that have already been mounted into clinical attitudes and for initiating trials in common conditions with a serious outcome, such as atrial fibrillation and stroke, to resolve at least some of the uncertainties that confronted our respondents.

We thank the members of the Association of Physicians of Great Britain and Ireland and of the British Cardiac Society for allowing us to encroach on their time.

\section{References}

1 White PD. Heart disease. New York: Macmillan, 1935

2 Lewis T. Diseases of the heart. London: Macmillan, 1942

3 Pickering GW. High blood pressure. London: Churchill, 1955.

4 Short D. The diastolic dilemma. Br Med f 1976; ii:685-6.

5 Hodes C, Rogers PA, Everitt MG. High blood pressure: detection and treatment by general practitioners. Br Med f 1975;i:674-7.
6 Taylor L, Foster MC, Beevers DG. Divergent views of hospital staff on detecting and managing hypertension. BrMed f 1979;i:715-6.

Manek S, Rutherford J, Jackson SHD, Turner P. Persistence of divergent views of hospital staff in detecting and managing hypertension. Br Med f 1984;289:1433-4.

8 Mitchell JRA. Hypertension and stroke. In: Harrison MJG, Dyken ML, eds. Cerebral vascular disease. London: Butterworths, 1983.

9 Medical Research Council Working Party on mild to moderate hypertension. Randomised controlled trial of treatment for mild hypertension: design and pilot trial. BrMed f 1977 ;i:143740.

10 Amery A, De Schaeparijver A. (European working party on high blood pressure in the elderly.) Organisation of a double-blind multi-centre trial on antihypertensive treatment in elderly Organisation of a double-blind multi-centre trial on antihype

11 Campbell A, Caird, FI, Jackson TFM. Prevalence of abnormalities of electrocardiogram in old people. Br Heart f 1974;36:1005-11.

12 Wolf PA, Dawber TR, Emerson Thomas H, Kannel WB. Epidemiologic assessment of chronic atrial fibrillation and risk of stroke: the Framingham study. Neurology (NY) 1978;28:973-7.

13 Lowe GDO. Anticoagulants in cardiac thromboembolism, cardiac surgery, peripheral arterial disease and cerebrovascular disease. In: Meade TW, ed. Anticoagulants and myocardial infarction: a reappraisal. Chichester: Wiley, 1984.

14 Canadian Co-operative Study Group. A randomised trial of aspirin and sulfinpyrazone in threatened stroke. N Engl f Med 1978;299:53-9.

15 Hampton JR. Coronary artery bypass grafting for the reduction of mortality: an analysis of the trials. Br Med J 1984;289:1166-70.

(Accepted 22 fuly 1986)

\title{
Assessment of need for coordinated approach in families with victims of head injury
}

\author{
MARTIN G LIVINGSTON
}

\begin{abstract}
Forty two men with severe head injury, and 41 with minor head injury, together with their families, were assessed at home after the injury. Despite significant impairment with respect to physical symptoms, personality difficulties, and occupational status in severely injured patients after one year, there was a very poor uptake of hospital rehabilitation facilities. In addition, patients' relatives showed significant psychosocial impairment throughout this period.

There is a need for a specialist to coordinate rehabilitation services for patients with head injury and their relatives and, in particular, to integrate physical and psychological aspects of management with a multidisciplinary team approach. Although this task will require specialist hospital teams for future development, at present general practitioners have some specialised knowledge that would enable them to coordinate rehabilitation.
\end{abstract}

\section{Introduction}

Rehabilitating patients with head injury is a priority, not only because of the amount of disability in physical, psychological, and social functioning that occurs in a group of patients who would normally be economically active, ${ }^{12}$ but because those studies that have been performed indicate an appreciable burden on the relatives from having to care for such patients. ${ }^{3}$ Patients may suffer from mobility problems, sensory loss, cosmetic and orthopaedic deficits, and cognitive impairment as well as personality change. They are often dependent on relatives for their care. Relatives complain at

\footnotetext{
Department of Psychological Medicine, University of Glasgow, Glasgow G12 OAA

MARTIN G LIVINGSTON, MD, MRCPSYCH, senior lecturer and honorary consultant at Gartnavel Royal and Gartnavel General Hospitals, Glasgow.
}

present of inadequate or poorly understood information. ${ }^{+}$They may have experienced psychiatric and social difficulties themselves after a patient with head injury has returned home. ${ }^{56}$ Relatives' psychosocial distress often takes the form of disorders of mood, especially anxiety, and a difficulty in fulfilling normal social roles, particularly within the family home. ${ }^{6}$

The present system of management of severe head injury after discharge from hospital in the United Kingdom generally consists of follow up at the clinic of the admitting acute specialty, ${ }^{7}$ though there are some specialist rehabilitation centres. ${ }^{8}$ Family doctors may therefore be left with a group of patients experiencing several handicaps and living in families suffering from psychosocial distress. We studied the need for rehabilitation and its uptake in families with patients suffering from head injury living in the west of Scotland, with a view to examining the role of the general practitioner and hospital services in long term management.

\section{Patients and methods}

A full description of the methods is published elsewhere. ${ }^{56}$ The population studied comprised 42 consecutive men admitted to a regional neurological service with severe head injury and 41 men with minor head injury who had been admitted to a general hospital for observation. Patients were said to have severe head injury if they had post-traumatic amnesia of duration greater than 48 hours and a Glasgow coma score of less than eight." Patients were said to have minor head injury if they had been admitted to the short stay ward for less than 48 hours and had sustained no more than soft tissue damage. Both groups of patients, together with a female relative, were seen at home three months after injury, and the families with severely injured patients were followed up at six and twelve months after injury. If the men were married their wife was seen, while for single men the relative interviewed was the mother; in both cases the relative had to be living with the patient in the family home.

Patients were assessed with the Glasgow assessment schedule, ${ }^{10}$ which is designed to provide a comprehensive rating of the patient's needs for rehabilitation. The schedule has six subscales that evaluate subjective complaints, physical signs, activities of daily living, occupational status, cognitive functioning, and behavioural change. High scores indicate more severe deficits. Problems covered by subjective complaints, physical signs, 
cognitive functioning, and personality change had to be at least moderately severe before they could be rated. The intention was not to record trivial, non-specific symptoms, such as minor headaches, that are often present in a normal population. The general health questionnaire 60 was used to determine psychological functioning in the relatives, ${ }^{11}$ and their perception of the patients' problems was assessed with the perceived burden scale. 5

\section{Results}

\section{REHABILITATION ASSESSMENT}

At three months the severely injured men were significantly more handicapped in all spheres of functioning except employment (table I). This exception may, however, be due to prevailing socioeconomic conditions.

TABLE I-Outcome in patients three months after injury

\begin{tabular}{|c|c|c|c|c|}
\hline \multirow[b]{2}{*}{$\begin{array}{l}\text { Variable } \\
\text { (maximum score) }\end{array}$} & \multicolumn{2}{|c|}{ Median score } & \multirow[b]{2}{*}{$\begin{array}{c}\text { Mann-Whitney } \\
\text { U test }\end{array}$} & \multirow[b]{2}{*}{$\begin{array}{l}\text { Two tailed } \\
\text { probability }\end{array}$} \\
\hline & $\begin{array}{l}\text { Mildly injured } \\
\quad(\mathrm{n}=\mathbf{4 1})\end{array}$ & $\begin{array}{l}\text { Severely injured } \\
\quad(n=42)\end{array}$ & & \\
\hline Activities of daily living (16) & 0 & 1 & $341 \cdot 50$ & $\mathrm{p}<0.001$ \\
\hline Unemployed (yes or no) & 0 & 0 & $\begin{array}{c}0.02 \\
\left(\gamma^{2} \text { test }\right)\end{array}$ & $\mathrm{p}<0.88$ \\
\hline Unemployable (yes or no) & 0 & 1 & $\begin{array}{r}24 \cdot 86 \\
\left(\gamma^{2} \text { test }\right.\end{array}$ & $\mathrm{p}<0.001$ \\
\hline Subjective complaints (34) & 1 & 7 & $176 \cdot 50$ & $\mathrm{p}<0.001$ \\
\hline Personality change $(8)$ & 0 & 2 & 404.00 & $\mathrm{p}<0.001$ \\
\hline Cognitive functioning $(70)$ & 0 & 0 & $471 \cdot 50$ & $\mathrm{p}<0.001$ \\
\hline Physical signs (16) & 0 & $1 \cdot 5$ & $323 \cdot 00$ & $\mathrm{p}<0.00 \mathrm{l}$ \\
\hline
\end{tabular}

The severely injured patients had significantly greater deficits in subjective complaints, physical signs, cognitive functioning, personality change, and skills of daily living $\left(\mathrm{p}<0.001\right.$, Mann-Whitney U or $\chi^{2}$ test). Common problems in these patients were walking difficulties, dysarthria, and poor retention of information and concentration, as well as apathy, lack of motivation, irritability, and aggression. In addition, these psychological factors were complicated in many patients by poor hearing or eyesight resulting from the injury.

Table II shows the relatives' responses to the general health questionnaire three months after injury. The scores of the relatives of the severely injured were on average very high, and the difference between the two groups of relatives indicates significantly poorer psychological adjustment for those related to the severely injured patients. The high scores reflect anxiety based symptoms, both physical and somatic, and many relatives indicated in their response their feeling of being unable to cope.

TABLE II-Psychological functioning of relatives three months after injury

\begin{tabular}{lcccc}
\hline & $\begin{array}{c}\text { No of } \\
\text { patients }\end{array}$ & $\begin{array}{c}\text { Mean (SD) score } \\
\text { on general health } \\
\text { questionnaire }\end{array}$ & $t$ & $\begin{array}{c}\text { Two tailed } \\
\text { probability }\end{array}$ \\
\hline $\begin{array}{l}\text { Relatives of patients with: } \\
\text { Minor injury } \\
\text { Severe injury }\end{array}$ & 37 & $\begin{array}{c}5.35(6.97) \\
10.17(10.34)\end{array}$ & 2.45 & $\mathrm{p}<0.02$ \\
\hline
\end{tabular}

The mean perceived burden score of the relatives of patients with minor injury was 1.83 (SD 2.27) and of the severely injured patients' relatives $7 \cdot 24$ $(4 \cdot 91)$. Relatives found that the greatest burden was personality problems in the patients, often complaining of aggression, childish regressed behaviour, and apathy. The difference between the perceived burden scores in the two groups of relatives was also significant $(t=6.47, \mathrm{p}<0.001)$, indicating that relatives of the severely injured thought that they had greater problems in living with the patients.

The severely injured patients and their relatives were more handicapped at this early assessment after discharge. To see whether they required rehabilitation their progress over one year was also assessed, and the assessments at three and 12 months were compared. Table III shows such a comparison of outcome for the severely injured patients. Thirty seven patients were seen at both assessments, the loss of five patients being due to admission to long stay care (two patients) and separation from their close relative (three). Recovery in terms of physical functioning was significant, corresponding to clinical improvement in dysarthria, diplopia, and walking ability. Cognitive functioning also improved significantly, mainly because of improvement in retention and concentration. Activities of daily living showed particularly significant improvement, possibly mirroring the improvement in physical capacity coupled with relatives' efforts to encourage independence in the home.

TABLE III-Outcome over one year for severely injured patients

\begin{tabular}{|c|c|c|c|c|}
\hline $\begin{array}{l}\text { Variable } \\
\text { (maximum score) }\end{array}$ & $\begin{array}{c}\text { Median (range) } \\
\text { score at } \\
\text { three month } \\
\text { assessment }\end{array}$ & $\begin{array}{c}\text { Median (range) } \\
\text { score at } \\
12 \text { month } \\
\text { assessment }\end{array}$ & $\begin{array}{l}\text { Wilcoxon's } \\
\text { matched } \\
\text { pairs }\end{array}$ & $\begin{array}{l}\text { Two tailed } \\
\text { probability }\end{array}$ \\
\hline Subjective complaints (34) & $7 \quad(16)$ & $7(21)$ & 0.98 & $\mathrm{p}<0.33$ \\
\hline Physical signs (16) & $1.5(13)$ & I (10) & $2 \cdot 34$ & $\mathrm{p}<0.02$ \\
\hline Personality change (8) & $2(6)$ & $2(8)$ & 0.13 & $p<0.90$ \\
\hline Cognitive function $(10)$ & $0 \quad 8$ & $0(6)$ & $2 \cdot 28$ & $\mathrm{p}<0.02$ \\
\hline Activities of daily living (16) & 1 (13) & $0(10)$ & $3 \cdot 86$ & $\mathrm{p}<0.001$ \\
\hline Unemployed (yes or no) & 0 & 0 & $\begin{array}{c}0.45 \\
\left(\chi^{2} \text { test }\right)\end{array}$ & $p<0.50$ \\
\hline Unemployable (yes or no) & 0.5 & 0 & $\begin{array}{c}3 \cdot 81 \\
\left(\chi^{2} \text { test }\right)\end{array}$ & $\mathrm{p}<0.05$ \\
\hline
\end{tabular}

The mean scores for the general health questionnaire at three months and 12 months after injury were 10.25 (SD 10.80) and 10.57 (15.62), respectively, for the relatives of the severely injured. This slight deterioration in their already poor psychological functioning was not, however, significant. The perceived burden scores at three and 12 months were $7 \cdot 40(5 \cdot 10)$ and $6.78(5.73)$, respectively. This difference was also not significant. These results indicate considerable residual incapacity in patients and consequent continuing impact on their relatives one year after injury to the head had occurred. Many of the problems in patients as well as relatives were behavioural and psychological.

\section{UPTAKE BY PATIENTS AND RELATIVES OF REHABILITATION FACILITIES}

At three, six, and 12 months after injury in 37 severely injured patients seen on all three occasions, 31,28 , and 30 , respectively, were not making use of any rehabilitation facilities. Two patients at each stage were receiving physiotherapy, and one at each stage was receiving occupational therapy. Only one patient was receiving work oriented rehabilitation six months after injury, and two, four, and three patients were receiving speech therapy at three, six, and 12 months after injury, respectively. All patients were reviewed at neurosurgical head injury follow up clinics. Ten patients were receiving anticonvulsant drugs throughout the one year of follow up as prophylaxis for traumatically induced seizures.

Of the relatives, most did not take up rehabilitation with the patients. Only one relative received help from a social worker. Fourteen relatives, however, were receiving anxiolytic drugs from general practitioners at three months after the injury, 15 at six months after injury, and 14 at 12 months after injury. In all cases these were minor tranquillisers of the benzodiazepine group.

Despite the fact that two thirds of the patients had been drinking heavily before the injury none of the patients or their relatives had availed themselves of the extensive alcohol support and counselling facilities available in Strathclyde.

\section{Discussion}

Three months after severe head injury this neurosurgical population had significant psychological, social, and physical deficits that were having a psychological impact on their relatives. Many deficits remained in both patients and relatives as the year progressed, particularly those of a behavioural and psychological nature. Despite the persistence of these deficits there was a very low uptake of rehabilitation services by the families. Nevertheless, a few relatives did attend the self help organisation Headway ${ }^{12}$ for relatives of victims of severe head injury.

Rehabilitation facilities in general do not seem to be well developed in the United Kingdom. Two surveys in London showed that a group of patients with severe head injury had been in acute wards for up to $2 \frac{1}{2}$ years, and many more had returned home to a life of inactivity. ${ }^{8}$ Certainly, there is a great lack of facilities offering 
psychological management after head injury, ${ }^{13}$ and this is a particularly important gap in services, bearing in mind the significant behavioural and psychological deficits that follow severe head injury. This contrasts with the United States, where there are many centres offering comprehensive rehabilitation programmes.

The almost complete failure of this sample of patients to obtain rehabilitation is not simply a reflection of the poor resources available. Patients with head injury have multiple problems and as a consequence often see several hospital specialists, none of whom has an overall view of the patient. Patients and their relatives are often unable to cope with this piecemeal approach to longer term management, and they default from attendance at clinics when the pace of recovery slows down. This, of course, is a crucial time when a concerted effort at rehabilitation could improve motivation. The present approach tends to tackle physical aspects of head injury outcome, with patients being directed towards physiotherapy when psychological deficits are often more persistent and burdensome.

If patients are not to fall through the net of the present rather meagre resources a coordinated approach towards their long term management is required. Ideally, such an approach should be managed by specialists from psychiatry and rehabilitation medicine who are prepared to work with multidisciplinary teams. Such teams would require psychologists, occupational therapists, physiotherapists, and nursing services, as well as medical workers. Programmes could be tailored to meet the individual needs of patients and their families.

This study shows that in the west of Scotland general practitioners are responsible for much of the long term management of patients with head injury and their families. In some respects family doctors are well equipped to deal with such patients, particularly as they have an overall view of the patient and his family. The detection of alcohol problems associated with the injury in two thirds of the cases described in this study should lead to effective counselling in the surgery and direction towards appropriate resources-for example, Alcoholics Anonymous or the councils on alcoholism. General practitioners are also able to organise appropriate referral for the management of problems associated with the multiple injuries that many victims of severe head injury encounter. Orthopaedic problems often complicate neurologically based ataxia, speech impairment, and cosmetic deficits after the injury.
Attention to these deficits, as well as many other handicaps, depends to some extent on the stamina of patients for continuing treatment. General practitioners should also be aware of the availability of local services for occupational therapy, speech therapy, and physiotherapy, together with local psychiatric and psychological services for patients and their relatives.

By virtue of their prolonged contact with patients' families many general practitioners develop a good understanding of the family structure and its ability to withstand stress and of underlying marital discord and other relationship difficulties in the household. This understanding is vital, as the consequences of severe head injury can include permanent unemployment, persistent personality problems, and reduced or absent sexual activity. ${ }^{14}$ is

Thanks are due to Mrs S Neilson for typing the manuscript.

\section{References}

1 Jennett B. Research aspects of rehabilitation after acute brain damage in adults. Lancet 1982 ;i: $1034-6$

2 Jennett B, Snoek J, Bond MR, Brooks DN. Disability after severe head injury: observations on the use of the Glasgow Outcome Scale. I Neurol Neurosurg Psychiatry 1981;44:285-93.

3 Livingston MG. Families who care. Br Med f 1985;291:919-20.

4 Panting A, Merry PH. Long term rehabilitation of severe head injuries with particular reference to the need for social and medical support for the patient's family. Rehabilitation 1972;38:33-7.

5 Livingston MG, Brooks DN, Bond MR. Three months after severe head injury: psychiatric and social impact on patients' relatives. I Neurol Neurosurg Psychiatry 1985;48:870-5.

6 Livingston MG, Brooks DN, Bond MR. Patient outcome in the year following severe head injury and relatives' psychiatric and social functioning. 7 Neurol Neurosurg Psychiatry 1985;48:876-81. Anonymous. Caring for the disabled after head injury [Editorial]. Lancet 1982;ii:948-9.

8 Gloag D. Services for people with head injury. Br Med f 1985;291:557-8.

9 Teasdale G, Jennett B. Assessment of coma and impaired consciousness: a practical scale. Lancet 1974 ;ii:81-4.

10 Livingston MG, Livingston HM. The Glasgow Assessment Schedule: clinical and research assessment of head injury outcome. Int Rehabil Med 1986;7(4):145-9.

11 Goldberg D. Manual of the General Health Questionnaire. 1978. Windsor, Berkshire: National Foundation for Education and Research Publishing Co.

12 Gloag D. Rehabilitation after head injury. 2. Behavioural and emotional problems, long term needs, and the requirements for services. Br Med $\mathcal{F}$ 1985;290:913-6.

13 Gloag D. Needs and opportunities in rehabilitation: rehabilitation after head injury. 1. Cognitive problems. BrMed F 1985;290:834-7.

4 Brooks DN, Campsie L, Symington C, et al. The five year outcome of severe blunt head injury: a relative's view. I Neurol Neurosurg Psychiatry 1986;49:764-70.

5 Brooks DN, Campsie L, Symington C, et al. The effects of severe head injury upon patient and relative within 7 years of injury. Brain Injury (in press).

(Accepted 28 fuly 1986)

\section{MATERIA NON MEDICA}

\section{Miracle in Wharfedale}

The priory church of St Mary and St Cuthbert at Bolton in Wharfedale, popularly known as Bolton Abbey, is a place of unique interest, both architectural and historical. It was founded about 1150 by Alice de Romilley, a wealthy Norman lady, "for the good of her soul," as it is recorded, although there is also a legend that the real reason for the foundation was the tragic death of her son, the Boy of Egremont, in the Strid, a spectacular gorge where all the waters of the Wharfe pour through a narrow cleft in the rocks and tempt the daring and unwary to a leap; it remains a beautiful but dangerous place to this day and over the years has claimed many victims. Historians deny the legend, but not so William Wordsworth, for, hearing the story on a visit to Bolton at the beginning of the last century, he committed the episode to verse in the poem "The Force of Prayer."

Whatever the truth of the matter, Bolton became an established Augustinian priory, and at Henry VIII's dissolution of the monasteries would no doubt have suffered the fate of Fountains, Rievaulx, Kirkstall, and other Yorkshire abbeys, had it not been for the insistence of the last prior, Richard Moone, who successfully claimed the right for the nave to be retained as a church for the parish; and so it has remained to this day.

In its present structure the priory church is unique: the choir and sanctuary, together with the eastern end, an elegant Gothic ruin, with the church itself squeezed in between the ruins and the unfinished west tower on which Richard Moone was at work at the dissolution. Since that time it has acted as the parish church that Moone envisaged, no doubt with its ups and downs but continuing as a place of worship, and beautifully situated in a bend of the Wharfe in Bolton Woods, a great place for visitors, though many would pass it by as just another of those old Yorkshire ruins and miss the church altogether.

Recently, in the 'sixties and 'seventies, however, the church deteriorated and by 1978 was in a sad state of spiritual and physical decay; the congregation had dwindled to a handful, and at the diocese the solution seemed to be closure, for the last rector had retired and no successor was around to take on what appeared to be an impossible task. Yet one man did present himself and accept the challenge, armed with faith, fortitude, and enthusiasm and supported by the queen of all rectors' wives. He first established and then maintained an "old fashioned" service of Sunday morning worship based on the old prayer book with no alternative sop to any modern trend. He then aroused both local and countryside interest in his ideas for the necessary repairs to the fabric of the church-this entailing the raising of a sum of nearly $£ 400000$ - and as he worked his congregation and their spirit and enthusiasm grew.

When he retired, worn out, in the autumn of 1985 after less than eight years, the physical restoration of the church had been completed, the Sunday congregation was into three figures, and the priory church itself a place of worldwide pilgrimage drawing more than a quarter of a million visitors a year. Now, of course, it was the jewel in the diocesan crown and there were no fewer than 74 applicants for the appointment of the new rector-verily the stone which the builders had rejected. The hour and the place brought forth the man, you may say, or could you just be prepared to believe in miracles? - C L DAvIDSON, retired consultant physician, Skipton, Yorkshire. 